\section{茅を下地とした逆莫きの葈莫き 小屋の構法}

一別府市明礬温泉の湯の花小屋一
THE CONSTRUCTION OF THE THATCH ROOFING OF THE RICE STRAW USING THE UNDERLAY OF THE JAPANESE SILVER GRASS

- The Yunohana Hut at the Myoban hot spring in Beppu City -

\section{釜床美也子—— $* 1$}

キーワード :

茅莫き, 伝統構法, 小屋

Keywords:

Thatched roof, Traditional construction, Hut

\section{Miyako KAMATOKO — * 1}

This paper intends to reveal the construction of the thatch roofing of the rice straw using the underlay of the Japanese silver grass. I researched for the "Yunohana Hut" had been built for producing the bath additive at the Myoban hot spring in Beppu City. The hut's roof had been needed to the performance for keeping warm and discharging humidity, so the farmers had been kept making the thatch roofing. The thatched roof was built up from layers of the $150 \mathrm{~mm}$-thick underlay of the Japanese silver grass and $150 \mathrm{~mm}$-thick roofing of the rice straw. The Japanese silver grass filled the role keeping the room warming, and the rice straw was used as the roof material for good runoff of water.

\section{1. 研究の背景と目的}

茅莫きの莫き方には、根元を外に向けた「真葺き」と穂先を外に 向けた「逆蕞き」がある。逆莫きは、根元より腐りやすい穂先側が 露出するため、真莫きに比べ耐久性に劣る。しかし、真莫きは単純 に莫き重祇ると徐々に緩勾配になるため捨て茅を必要とし、結果的 に厚い屋根になるのに対し、逆莫きは穂先が下がるため薄くても雨 仕舞の良い屋根となる。日本の本土では、本格建築は真莫き、仮設 建築は逆蕞きが用いられたと言われている(安藤 ${ }^{1)}$, 69)。元々長期 的な利用や完璧な雨仕舞を目的としない小屋のような簡易の建物で あれば、耐久性に劣ってもむしろ材料が少なく簡単に葺ける逆莫き が適していたと言える。これまでの茅莫きの構法に関する研究は、 技巧的な真莫きを対象としたものがほとんどで、逆莫きの構法に関 する研究は限定的と言える。しかし、その素朴な莫き方は原初的な 屋根のつくりを伝えている可能性があり、逆莫きの構法の詳細を明 らかにすることで茅莫きの技術体系を補完し、その多様性や技術的 幅を示すことができる可能性があると考えた。

既に逆莫きはほとんど見られなくなっていることから、建物が現 存し、かつ施工者へのヒアリングが可能な事例を探した結果、大分 県別府市明樊温泉にある湯の花小屋（写真 $1 、 2 ）$ が見つかった。湯 の花小屋は、温泉の不溶性成分が析出した湯の花と呼ばれる天然の 入浴剂を製造するための専用の小屋である。湯の花は明樊温泉で明 治 17 年に製造が開始され、茅莫き屋根によらなければ湯の花が製造 困難であったため、今日までその伝統的な逆莫きの小屋が作り続け られてきたのである注 ${ }^{11}$ 。湯の花小屋に関する既往研究には、恒松 ${ }^{2)}$ の歴史的な観点からの湯の花生産の研究がある他、別府市教育委員 会 ${ }^{3)}$ による小屋の残存数等の調査があるが、建築学の観点からの建

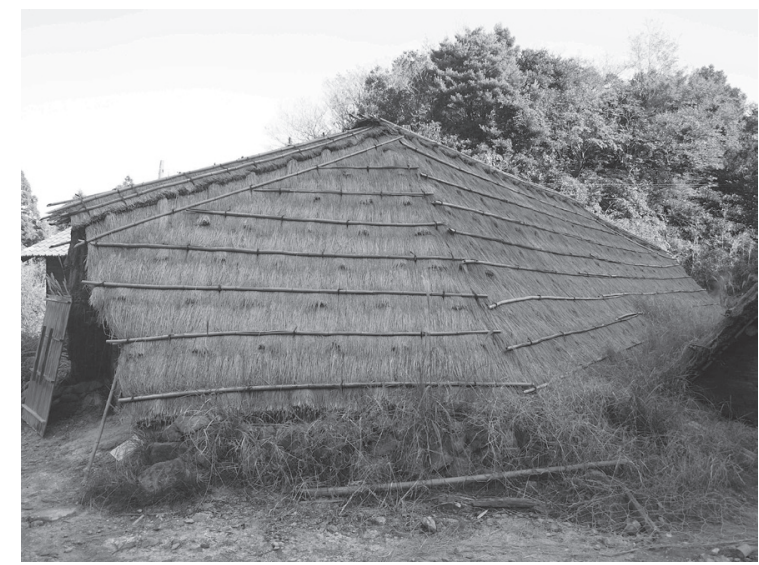

写真 1 湯の花小屋外観

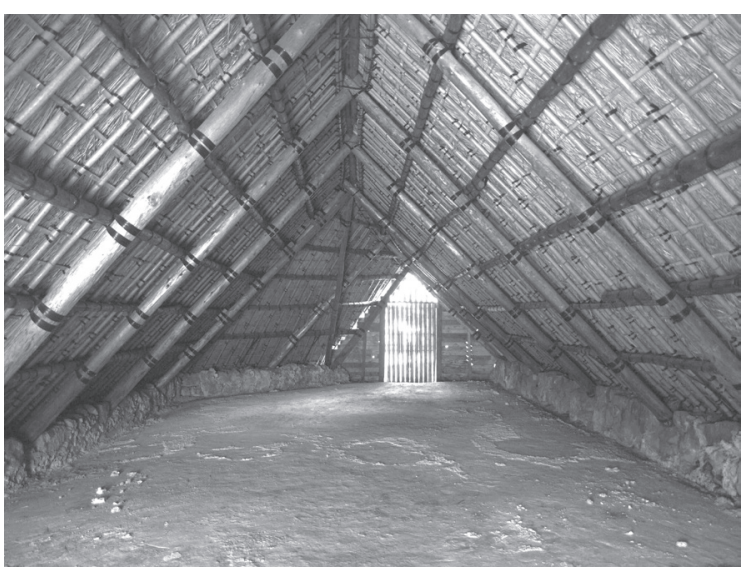

写真 2 湯の花小屋内観

本稿の一部は、文献 4) で発表している

(† 761-0396 香川県高松市林町 2217-20)

Research Assoc., Faculty of Eng., Kagawa Univ., Dr. Des. 
物の分析や、茅莫きの構法に関する記述は限定的であった。そこで 本研究は数少ない逆莫き技術を残寸事例としての湯の花小屋に着目 し、その屋根構法の特徴を明らかにすることを目的として研究を行 った。

\section{2. 研究の方法}

湯の花小屋は明樊温泉の明樊地区と湯山地区に見られるが、ヒア リングにより現在も小屋を建築して湯の花製造を行っているのは 2 地区あわせてわずか 4 軒だと分かった。別府市教育委員会への問い 合わせにより、小屋を建築しながら 3 代続けて湯の花を製造してき たという伝統的な小屋の建築技術に詳しい 1 名の技術者の紹介を受 けることができた。そこで平成 26 年 11 月 20 日に調查員 3 名にてそ の技術者に対するヒアリング調查と小屋の実測調查を実施した。施 工の手順や地下の構造については、ヒアリングの他、施工途中の写 真を入手して確認した。2 地区において構法が異なるとみられたも のについて実施した。湯の花小屋の耐久性は 20 年程度であるため既 に古い遺構は残っていなかったが、文献調查により明治 32 年から大 正期の間に撮影されたとみられる湯の花小屋の古写真を発見したた め、古い構法はそれに基づいて確認した。

\section{3．湯の花小屋の歴史}

湯の花は、ハロトリカイトとアルノーゲンの混合物である。小屋 の土間にこの地域に産する青粘土を敷き詰め、その下に噴気（硫化 ガス）を巡らせることで、化学反応により青粘土表面に湯の花の結 晶を密生させる。湯の花は早ければ 1 ケ月で $2 \sim 3 \mathrm{~cm}$ 程に成長し、土 間上をコテでこそぎ取って採取する。青粘土を一度床に敷き詰めれ ば $5 〜 6$ 回は結晶ができ、それが終わると一旦青粘土を廃棄してまた 新しく敷き詰める、という作業を繰り返す。こうした湯の花の生産 方法はこの地域独自のもので、湯の花小屋も明礬温泉にのみ見られ る建物である。湯の花は年間通して生産が可能であったことから、 副業として明治以降農家に広まった。生産の盛んだった大正 15 年に は明樊地区と湯山地区の生産者数は 45 人、小屋は 272 棟だったが (恒 松 $\left.{ }^{2)}, 54\right)$ 、平成 21 年の別府市教育委員会 ${ }^{3)}$ の調査では、2 地区の小 屋は 50 棟にまで減っている（ただし、そのうち稼働中・稼働可能 なものは 32 棟で、それ以外は屋根がなく軸組のみになった休止小屋 である)。

湯の花は、元はこの地域で盛んだった明䙪の製造工程の半製品で あった。明樊は止血剤や動物の革のなめし等に用いられ、江戸時代 に国内生産が盛んになった。別府市 ${ }^{5)}$ によれば、明樊温泉での明樊 生産は、寛文年間に渡辺五郎右衛門がその精製に成功したのが始ま りで、寛保年間には「豊後明樊」として国内の明樊生産の 7 割を占 める産業にまで発展していた。しかし、明治維新後に化学薬品の輸 入が増加したことで明樊事業は不振に陷り、明治 17 年に従業員の失 業対策として明樊に代わって半製品であった湯の花の入浴剤として の販売が開始された。湯の花は明礬に代わり販路を拡大し、明治末 から大正時代には明樊事業は湯の花製造に移行して安定した製造が 行われるようになった。

一方、湯の花製造の茅莫きの小屋の起源についてはほとんど明ら かになっていない。豊後明樊は明樊礬土と八イノキの木灰汁とで精 製され、半製品である湯の花が製造される小屋もあったはずだが、

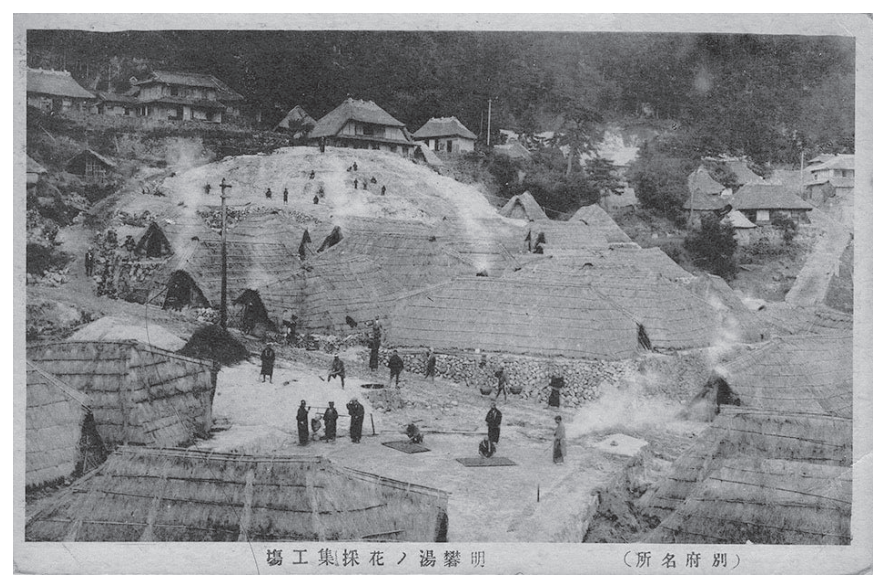

写真 3 絵葉書「別府名所 明樊湯ノ花採集工場」

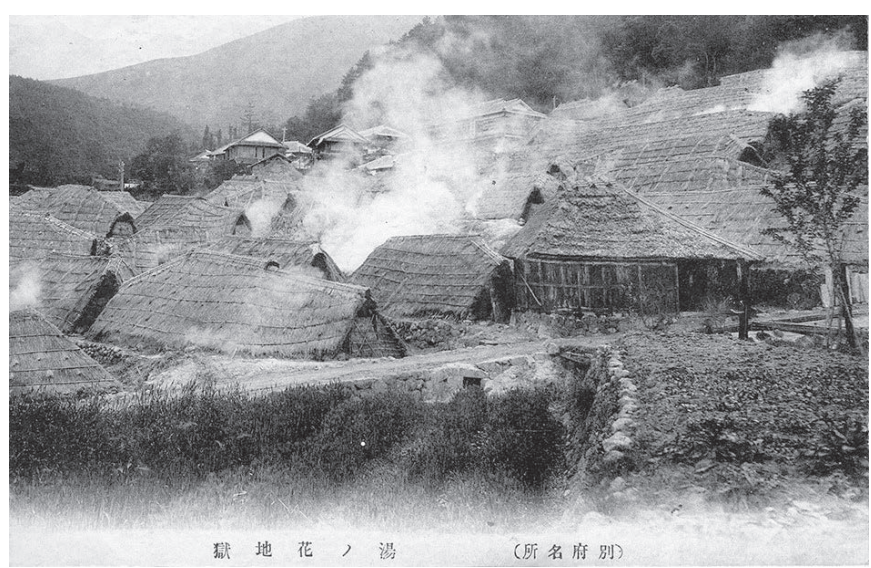

写真 4 絵葉書「別府名所 湯ノ花地獄」

明松の製造方法は跡継ぎにのみ伝えられる秘伝で、その工程の詳細 は明らかになっていないのである。江戸中期に貝原 ${ }^{6}$ が明樊製造法 の概要を述べた記録はあるが建物については触れられておらず、明 䙪製造の風景を描いた伊島 ${ }^{7)}$ の「鶴見七湯迺記」(弘化 2 年) にお いても湯の花小屋のような建物は確認できない。現時点で小屋の構 法が確認できる最古の資料は、今回見つかった明治 32 年から大正期 の間に絵葉書を販売していたという和田成美堂の別府絵葉書「別府 名所 明礬温泉湯ノ花採集工場」（写真 3 ）である。また、撮影年代 は不明であるが同時代に販売されたと見られる「別府名所 湯ノ花 地獄」(写真 4) の絵葉書が見つかった。いずれも現在と変わらない 小屋の外観が確認でき、その時点で構法は完成していたとみられる。 本研究でヒアリングを行った先述の技術者の話からも、祖父の代か ら小屋の作り方は変わっていないことが確認された。

\section{4. 小屋組}

\section{4-1. 構造}

小屋組はスギ丸太の双首組で、双首同士はホゾ差しとする。双首 尻は平滑で、サスジリと呼ばれる基礎石にも加工はなく、双首が直 接乗る注 ${ }^{2)}$ 。小屋組は、「本屋 (ほんや)」と呼ばれる切妻部分と、「妻」 と呼ばれる棟を斜めに下げた出入口の部分とに分かれる（一般的な 「妻」とは異なり、本屋に取り付いた図中部分の架構全体を指す)。 
ヒアリングにより判明した各部の名称を図 1 に示す。また、軸組の 模式図を図 2 に示寸。本屋の梁間は最大でも $5 \mathrm{~m}$ 程度までで、本屋部 分の扠首間隔は $1.8 \sim 2 \mathrm{~m}$ である。屋根勾配は、「梁間に対して双首の 長さを $3 / 4$ 程度」とだけ決められている(勾配に換算すると $\fallingdotseq 48^{\circ}$ )。 妻は出入口の双首 (A) と中 (なか) 双首とで構成される。出入口の 棟高は出入りに最低必要な高さとして $2.1 \mathrm{~m}$ 程度とする。本屋に比べ て低いため、妻の棟木は出入口に向かって下がり勾配になる。出入 口の棟高 $2.1 \mathrm{~m}$ は、小屋が大きくなり本屋の棟高が高くなっても変え ない。開口部が大きくなると、台風時等に強風が小屋内に入り、屋 根の弱い所を吹き抜くためといわれる。また、妻は平面的に本屋に 対して首を振るように適当な角度で曲げ（実測值で $19 \sim 20^{\circ}$ 程度）、 両側の出入口が点対称の位置に作られる。これも強風が小屋内を吹 き抜くことを防ぐためだという。

また、出入口の双首 (A) は直立ではなく外側に向かって傾斜させる。 本屋の両端の扠首 (B) の扠首尻も $20 \sim 40 \mathrm{~cm}$ 程度内側に控えて建て、 外側に向かって傾斜させる。ヒアリングによれば、出入口の双首 (A) を傾斜させるのは雨風を避けるためであり、本屋の端の扠首 (B)を傾 斜させるのは本屋全体を両側から引っ張ることで倒壊を防ぐためだ という。突っ張り (C) はその傾斜した本屋の端の扠首（B）の支持部 材である。角（かど）扠首は下り棟をつくるためのもので、その先端

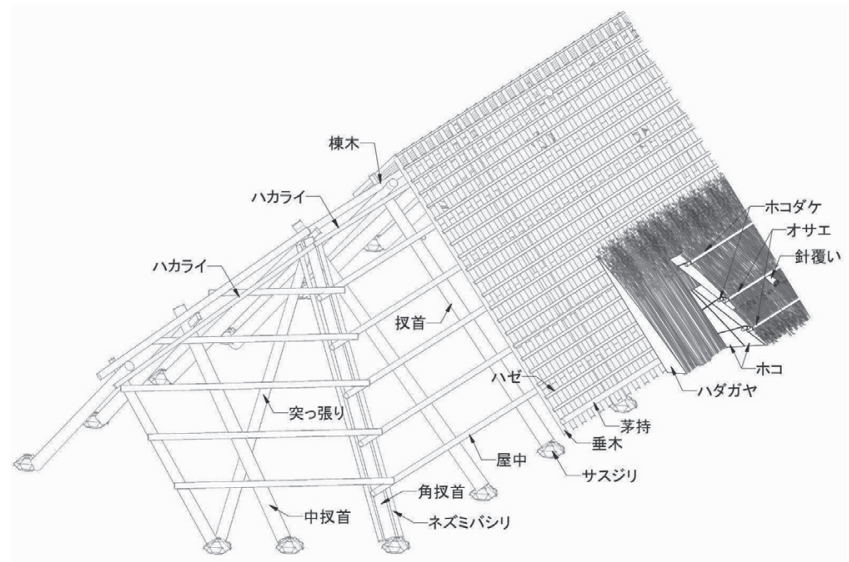

図 1 各部名称
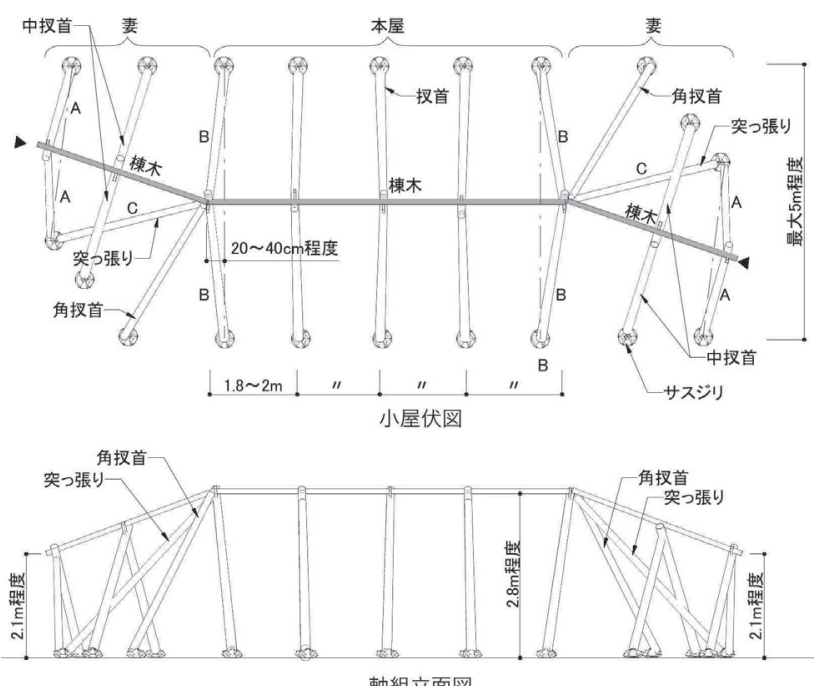

図 2 軸組の模式図 $s=1 / 200$
は棟木にホゾ差しとする。突っ張り (C)の先端は突き付けで、紐で縛 るのみである。突っ張り (C) の箇所は屋根が谷になるため、屋中との 間にスケモン (介もの)を入れて平に仕上げることが多い (写真 5)。

\section{4-2．土間の造成と建て方}

図 3 に実測した湯の花小屋の断面図を示す。施工は、最初にサス ジリを並べる。基礎は、写真 6 のようにサスジリだけのものと、石 積みの立ち上がりを築いた上に双首を置くものとがあり、前者が古 い構法である。後者はヒアリングを行った技術者の祖父が双首尻付 近の作業をやりやすくするために小屋を高くすることを考案したも ので、湯山地区に見られる。次に、土間部分を $400 \mathrm{~mm}$ ほど掘り下げ、

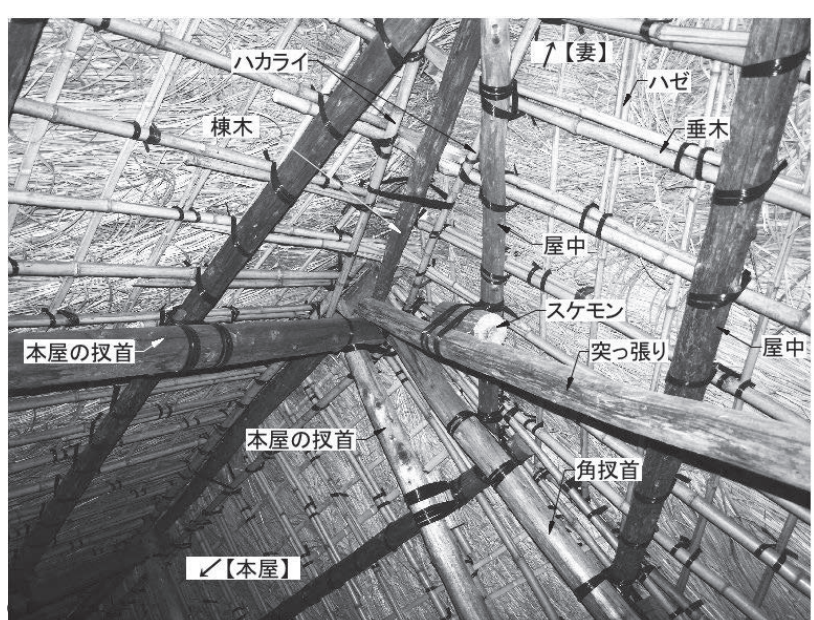

写真 5 本屋の双首・突っ張り・角扠首の取り合い部分

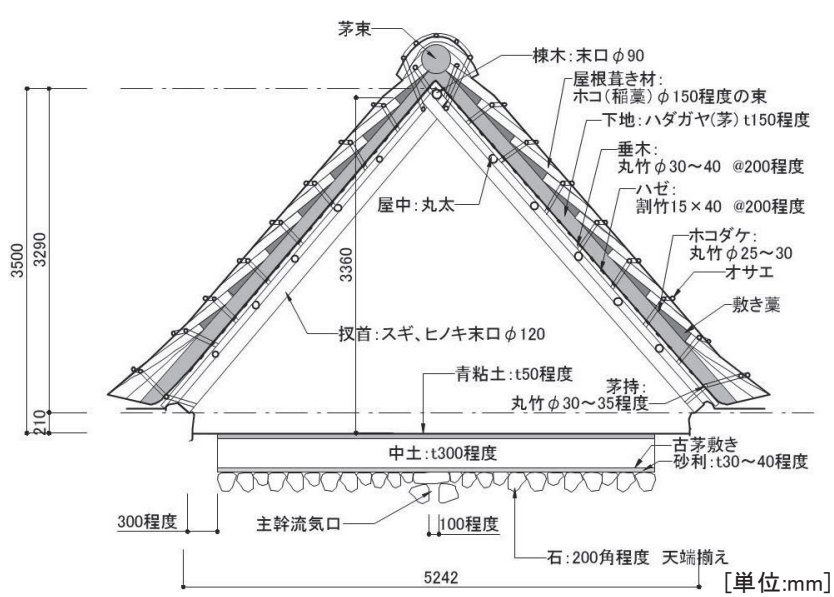

図 3 本屋部分断面図（湯山地区） $\quad \mathrm{s}=1 / 100$
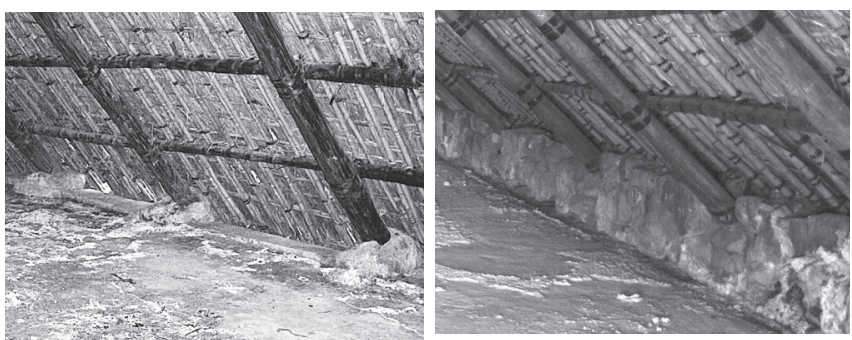

写真 6 サスジリのみの方法 (左) と石積み上に載せる方法 (右) 
硫気が通る $100 \mathrm{~mm}$ 幅程度の通路の主幹を小屋の端から端まで石を 並べてつくる。主幹に直交する梁間方向にも支幹の通路を延ばし、 土間全体にまんべんなく硫気が行き渡るようにする（図 4)。主幹は 2 本にする場合や、土間をループ状に巡らせる場合もある。主幹の 終端部は小屋の外に出た付近で煙突を設け、硫気を出す。そして、 主幹、支幹ともに硫気の通路の上に扁平な石を敷き並べて暗渠にし、 通路同士の隙間には $200 \mathrm{~mm}$ 角程度の石を敷き詰める。敷き詰める高 さは暗渠の蓋の石の天端にそろえる (前出図 3 参照)。硫気は暗渠を 通りながらそれらの敷き詰められた石の隙間に流れ出て小屋の床全 体に広がる。隙間を埋める石は尖った面を下部に向け硫気が入りや すくする。石を敷き詰める範囲は、硫気で双首尻が傷むため双首尻 から $300 \mathrm{~mm}$ 程度内側に控えた辺りまでとする。敷き詰めた石の上に は 30 40 mm 程砂利を入れ、さらにその上に古茅を敷き、掘り返した 土（中土[なかつち]と呼ばれる）を $300 \mathrm{~mm}$ 程の厚みになるように入 れて均し、土間部分が完成する。砂利や古茅は、中土が沈んで硫気 の通る石の隙間を塞がないようにするためのものである。湯の花の 製造を開始する時には、中土の上に青粘土を $50 \mathrm{~mm}$ 程入れて均す。

小屋組は、最初に本屋の全ての双首己棟木を建てる。次に出入口 の双首を建て、本屋の端の双首と出入口の双首を結ぶように下がり 勾配の棟木を乗せ、その棟木の高さにあわせて中双首を入れる。そ して本屋の通り上に角双首を入れ、角双首まで屋中を通して入れて 固める。最後に傾斜した本屋の双首に突っ張りを入れる。小屋の大 きさは建築予定の場所の地形や噴気の取り入れ位置に応じて決める ため、1 棟ごとに異なる。例えば、狭小地の多い明礬地区の小屋は 湯山地区に比べ小さい。本屋の両側に妻を付けるのが一般的な形で あるが、狭小地等で妻を付けられない場合は、数は少ないが本屋だ けの小屋 (屋根形状は切妻となり、「両切り」と言われる) や、片側 だけに妻を付けた小屋も建てられる。梁間を $5 \mathrm{~m}$ の最大幅とした場合 は、後は本屋の桁行方向を伸ばすことで規模を拡大する。小屋面積 が大きい程 1 棟あたりの湯の花の生産量は増えるが、作業者が少な い場合、面積が広いと中での作業が追いつかないという。青粘土は 掘って数日経つと乾燥して固くなり中土とのまとまりが悪くなる。 すると青粘土と中土の間に湯の花が吹き、粘土が剥離することもあ るという。一度乾いた青粘土は水を散布しても元には戻らないため、 およそ 1 日で小屋に敷き詰め終わる程度の小屋の規模が理想という。 均寸作業に数日かかると 1 棟の小屋内で湯の花の成長が異なること になり、管理上も不都合となる。2人の作業者の場合、梁間 $5 \mathrm{~m}$ 、全 長 $13.5 \mathrm{~m}$ 程度の小屋で青粘土を入れる作業がちょうど1日で終わる。

\section{5. 屋根}

屋根の下地は、垂木（孟宗竹 $\phi 30 \sim 40 \mathrm{~mm}$ 程度）を $200 \mathrm{~mm}$ 間隔でと め、その上に $15 \times 40 \mathrm{~mm}$ 程度の孟宗竹の割竹の八ゼ（元は $\phi 25 \sim 30 \mathrm{~mm}$ 程度の真竹の丸竹だったが、滑り落ちるとの理由で現在は割竹を使 用している）を同じく上下 $200 \mathrm{~mm}$ 間隔で取り付ける。垂木は棟木の 位置付近で鎌を使って割り折り、反対側の一番上のヤナカの付近に 先端がくるようにして棟木に引っ掛け、ズレ落ちを防ぐ（写真 7)。 一番軒先に近い最下端の八ゼは、出入口の破風部分も含めて茅持 (か やもち）という太い竹（丸竹 $\phi 30 \sim 35 \mathrm{~mm}$ 程度）をまわす（図 5)。茅 持は全ての双首の双首尻と結び、風による軒先の吹き上がりを防止 する。また、軒先の稲禀の垂れを防ぐ。

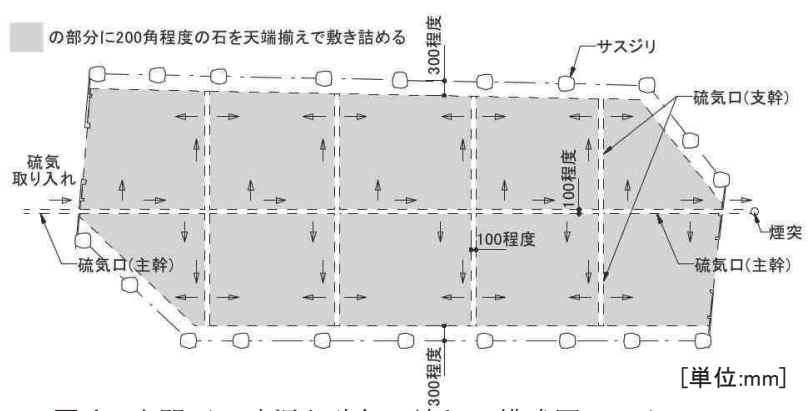

図 4 土間下の暗渠と硫気の流れの模式図 $s=1 / 200$

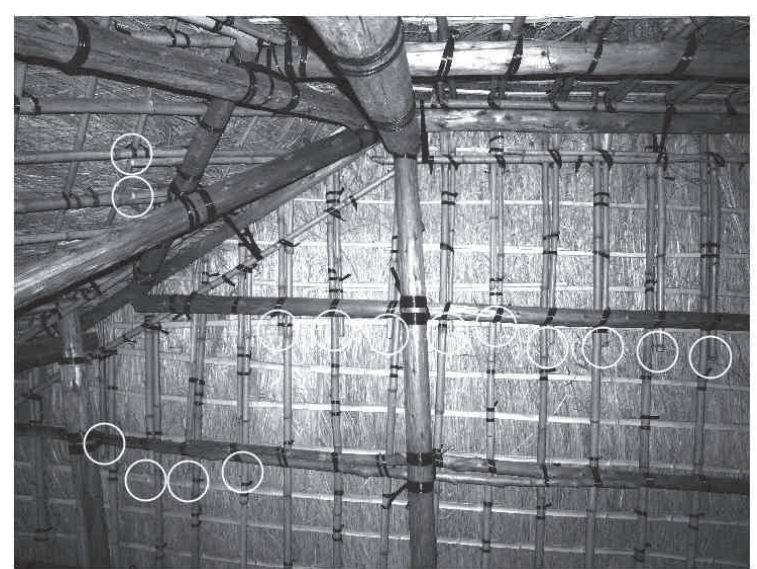

写真 7 垂木のズレ防止（○が反対側の垂木の先端）

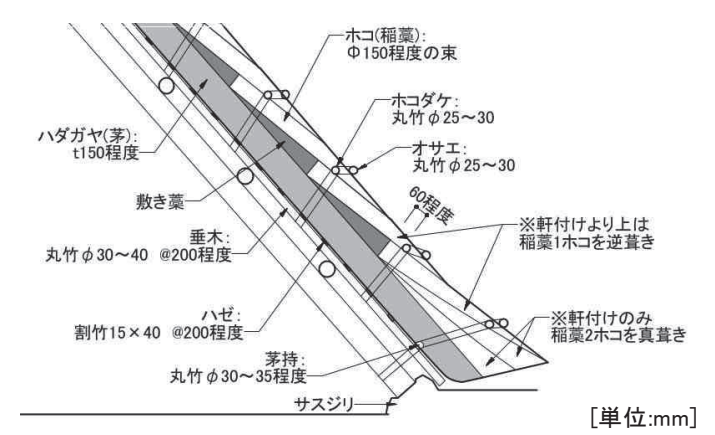

図 5 軒付け 断面詳細図 $s=1 / 50$

八ゼの上には八ダガヤと呼ばれる茅を縦に敷き並べる。八ダガヤ は上下の段で穂先の向きを逆にして全体を均等な厚みにする。ハダ ガヤの層は厚い程よいと言われるが、標準で $150 \mathrm{~mm}$ 程度である。八 ダガヤは、茅莫き屋根で一般的に使用される笠号ように屋根莫き材 （湯の花小屋の場合は稲葍）が小屋内に落下寸るのを防ぐ。垂木と 八ゼの間隔が密で籠のようになっているのは、その八ダガヤが土間 上の湯の花に落下寸るのを防止するためである。それでも茅の穂先 は垂れやすいため、垂れそうな部分は八ゼの上に並べる前にあらか じめ切り落とし、敷き並べた後も次第に垂れる葉を切る作業を行う。 屋根莫き材である直径 $150 \mathrm{~mm}$ 程に束补た稲营はホコと呼ばれる。 軒先は傷みや寸いため、軒付けのみ 2 ホコを真莫きにし、それ以降 は1 ホコの逆莫きとする。真莫きでは軒先の莫き厚が小屋全体の莫 き厚の基準になるのに対し、逆葺きは傷みやすい軒先のみ莫き厚を 厚くし、以降は逆莫きのホコの厚みが屋根厚になる違いがある。軒 先の真葺きの 2 ホコは、湯山地区ではそろえて軒先が屋根面に直角 
になるように並べるが、明樊地区では外側のホコを少し下にずらし て軒先が水平になるように並べる。垂木はサスジリの天端より低く なる程度まで伸ばし、屋根は地面ぎりぎりに葺く。軒先の真葺きの 2 ホコは、ホコダケ注 3 ) (丸竹 $\phi 25 \sim 30 \mathrm{~mm}$ 程度) で押さえて茅持に固 定する。それ以降の逆草きのホコはホコダケで押さえて垂木と固定 し、敷き葟を敷きながら 1 ホコ分の厚みで莫き上がる。上の段のホ コは、穂先が下の段のホコダケの結び目を隠す高さに置き、ホコダ ケは、ホコの根元から $60 \mathrm{~mm}$ 程下がったところに置く。そのため、逆 莫きが何段になるかは橖の長さに依る。ホコダケの結び目には、上 の段のホコを並べる際に根元側を下に向けたひとつかみの稲葈（針 覆い）を被せ、目を伏せる（写真 8)。ホコダケの結び目は 1 本の垂 木に集中しないように上下の段でずらすため、外観は針覆いが斜め に走る。ホコを垂木に留める結び方を図 6 に示す。踏み込んで一度 締めた後は緩まない男締めと呼ばれる結び方で、真莫きでも使われ る。結び目（針を入れる位置）の桁行方向の間隔は垂木 3 本おき (600mm 間隔程度) とする。1 ホコ分の厚みを基準として同じ段の厚 みをそろえ、谷になるのを防ぐ。各段のホコの下端はオサエ（丸竹 ф 25 30mm 程度）で抑え、オサエは下の段のホコダケと結ぶ。

棟まで莫き上がると、両側から伸びたハダガヤの穂先は反対側に

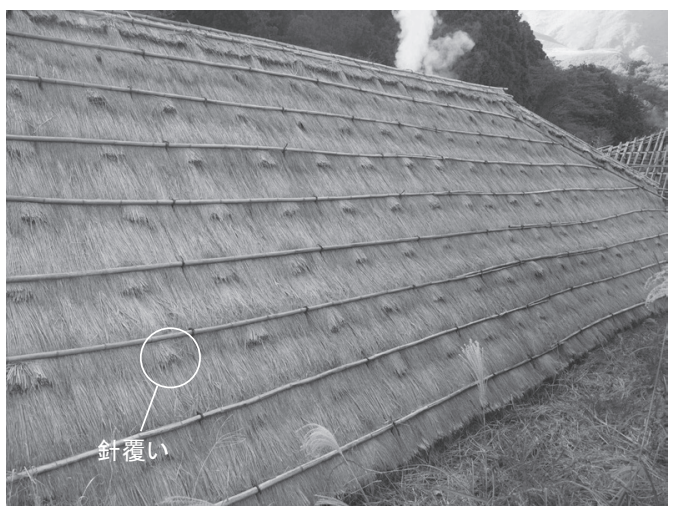

写真 8 針覆い
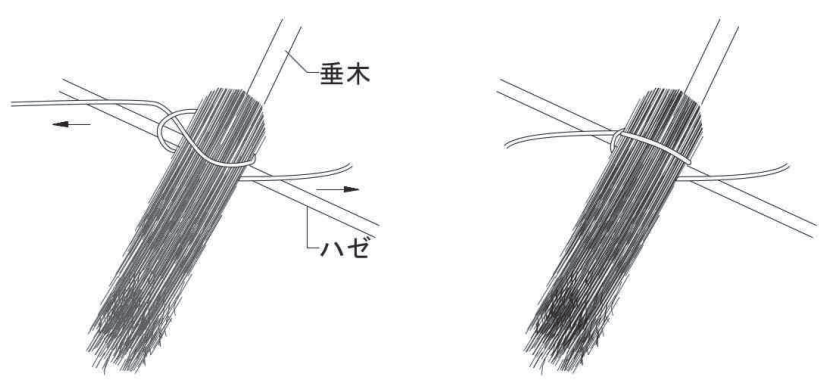

図 6 ホコの留め方（ホコダケとハダガヤは省略）

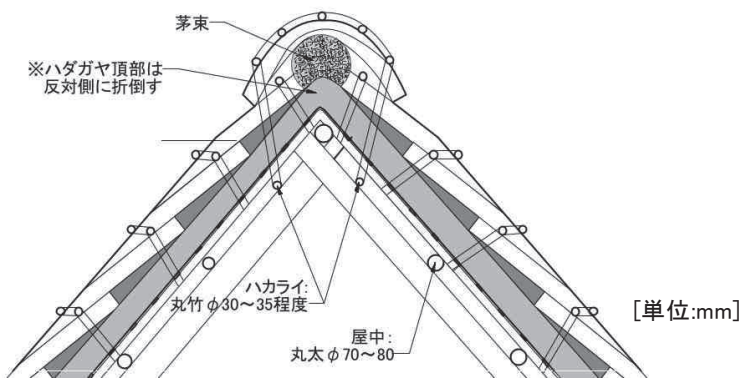

図 7 棟仕舞 断面詳細図 $\mathrm{s}=1 / 50$
倒し、厚みが足りない箇所に適宜茅を足して棟の上の高さをそろえ た後、棟の土台となる茅束を棟に沿って並べる（図 7)。そして茅束 の上に両側から穂先同士が頭あわせになるように稲葈を乗せて覆う。 そして稲㩰の押さえとして、あらかじめ 5 本の丸竹を $100 \mathrm{~mm}$ 程度の 間隔を空けて筫巻き状に結んだものを被せる（写真 9)。内部の棟木 の両脇には八カライ（丸竹 $\phi 30 \sim 35 \mathrm{~mm}$ 程度）と呼ばれる丸竹を 2 本 対で入れておき、稲葈を押さえた 5 本の丸竹の両端の竹をそれぞれ ハカライと結んで棟を固める。

全体の莫く順は、最初に傷みや寸い妻の出入口と角扠首の部分を 上まで葺き上がり、そのあと本屋を葺く。出入口の破風部分は、葍 を棟の傾斜と平行になるように横にして並べ、角扠首には茅束を巻 く。この茅束を止めるため、角双首の両脇にもネズミバシリと呼ば れる 2 本の丸竹を入れる (前出の図 1 参照)。建て方の開始から屋根 莫きを終えるまで、 1 人工で約 1 ケ月を要する。

\section{6. 茅壁と茅の戸}

出入口には、茅壁と取り外し可能な茅の戸がつく（写真 10）。現 在これらは入手しやすく加工の容易な木製に変わっているが、先述 の古写真でも当時は茅壁であったことが確認できた（写真 11）。葉 の部分が腐りやすいため、壁や戸に使用する茅は葉を落として茎だ けにする。茅の戸は、穂先同士を頭あわせにして並べ、木の角材で 挟んだものである。戸をつくるには 1 人で 1 日を要したといわれる。 茅壁は出入口に柱を 2 本立て、室内側に割竹の栈をあてて茅を入れ た後、外側からも割竹をあてて締めたものである。茅壁の上部は開 放になっている。中で作業をするための採光と換気のための開口部 で、特に青粘土を入れて均した後には大量の蒸気が出るため、その 排出を行う必要もあった。湯の花は結露すると溶けるため、特に冬 期は粘土を入れた直後の小屋内にこもる蒸気の排出が重要となる。

また、湯の花を現出させるためには適度な保温性も必要で、冬期

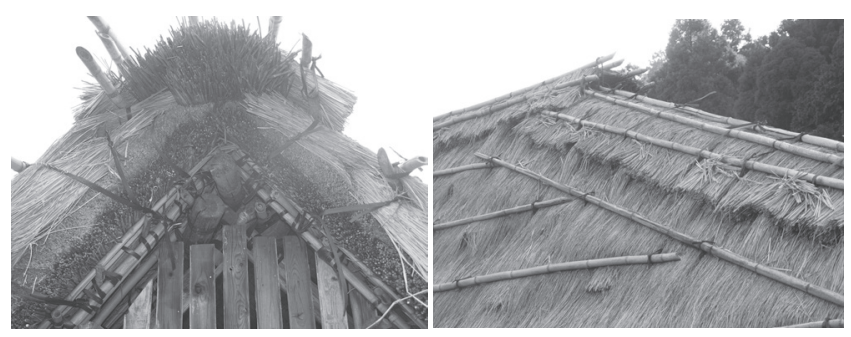

写真 9 棟の納まり
写真 10 現存する茅壁と茅の户

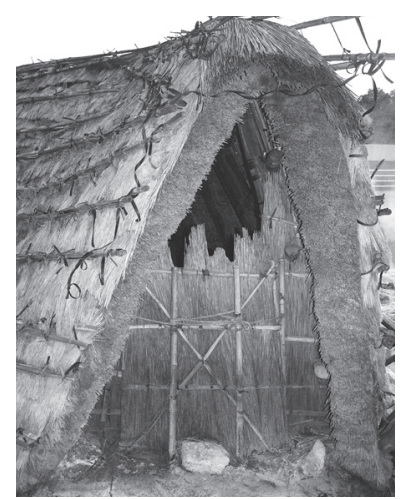

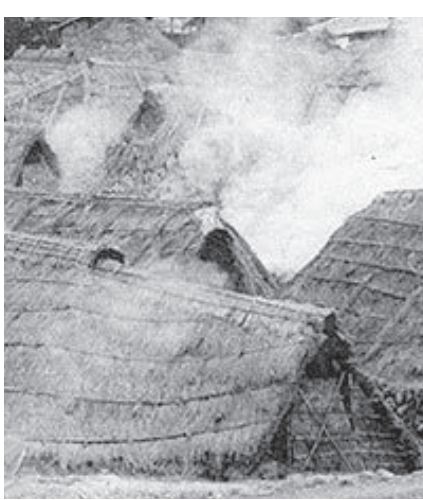

写真 11 写真 4 部分拡大 
は室温低下を防ぐ必要がある。恒松 ${ }^{8)}$ の計測（図 8）によれば小屋 の室温は最も低い 2 月でも $17^{\circ} \mathrm{C}$ 程度に保たれていることが分かる。

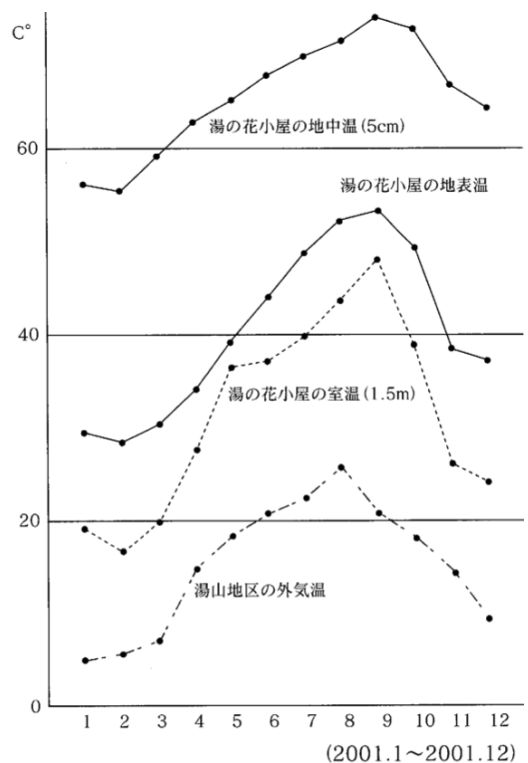

図 8 湯の花小屋の内と外の温度 $\left(\right.$ 恒松 ${ }^{8)}, 4$ から引用 $)$

\section{7. 維持管理}

1 棟の小屋を新築するには、茅は 50 把（1 把=直径 $40 \mathrm{~cm}$ 程度）、 葍は 120 130 束（1 束=36 ホコ程度）が必要と言われる。基本的に は屋根材の茅や㩰の耐用年数である 20 年が小屋の寿命で、その時に 全体を建て替える。建て替え時、小屋組のほとんどは再利用可能で ある。建て替えまでの 20 年間の維持管理としては、表面の稲㩰の層 を 3 年ごとに全て交換する作業がある。八ダガヤや敷き葍は少なく なったところに足す程度で、ほとんど交換の必要はない。雨漏りが なければ、棟の莫き直しも不要である。ただ、近年は稲菜の調達が 難しくなってきたため、稲葍を全て交換するのではなく、古い稲藻 の上に新しい稲菜を被せる補修方法が行われている。およそ 3 年に 1 回一旦ホコダケを取って表面の稲葈が沈んだ箇所に葈を足し、そ の上に新しい稲㩰のホコを乗せ、もう 1 層莫き重ねるのである。莫 き重ねは最初の層も含めて 3 層（3 年に 1 回葺き直すのでおよそ 9 年）まで行われる。それ以上になると、厚くなりすぎて垂木からま わした縄が下に垂れて屋根に穴があく可能性があり、締めるのも難 しくなるため、3 層が限度といわれる。3 層まで莫き重㸚た後は、ホ コを全て取ってまた 1 層で草き直す。

なお、小屋組は、先述のように双首の足元が硫気で煮えた場合に その双首だけが折れることがある。双首 1 本だけを交換するのは困 難なので、その場合は全て建て替えることになる。また、小屋内の 上部の八ダガヤが徐々に熱で黒くなり、土間に落ちるようになる。 その場合は部分的な莫き直しを行う。

\section{8. 考察とまとめ}

湯の花小屋に求められる性能は、風雨を凌ぐだけでなく、適度な 排湿と保温性という特別なものだった。湯の花小屋の逆葺きの稲葈 の屋根は、茅と稲葍を使い分けてその性能要求を満たした点が特徴 的と言える。すなわち、下地は $150 \mathrm{~mm}$ 程の厚い茅の層（ハダガヤ）
で断熱層とし、表面の屋根莫き材には雨仕舞のよい逆莫きの稲葍 (ホ コ）とする使い分けである。維持管理の点で言えば、耐久性の異な る茅と葍を組み合わせることで、莫き替えの手間と材料の節約が可 能になっていた。つまり、20 年は持つ下地の茅の層（ハダガヤ）は 交換せず、耐久性には劣るが薄くても雨仕舞のいい表面の逆葺きの 稲莕（ホコ）だけを 3 年で更新する仕組みである。湯の花小屋に求 められる保温性を持つ厚い屋根を、3 年程の耐久性しかない稲葈だ けでつくると、その更新には相当な労力と材料を要するといえる。 また、角双首や棟のような傷みやすい箇所には、耐久性を高めるた めに茅束を小屋組に巻き付け、その上に稲葍を被せる手法が確認さ れた。

湯の花小屋は、稲菜の逆莫きに茅壁という原初的な構法を残寸小 屋であった。軒先のみ真葺きにするという点は一般的な逆草きと共 通するが、男締めというホコの締め方や、竹の垂木を曲げて棟木に ひっかける点、茅持を用いる点、棟に茅束を用いる点など、真莫き の主屋と共通寸る技術も多数見られた。湯の花小屋はそうしたある 程度高度な技術が導入されているといえる。ただ、ヒアリングを行 った湯の花小屋を長年作ってきた技術者でも、真葺きの主屋の屋根 は葺けないといい、技術的な差異があることも明らかになった。今 後より原初的な逆莫きの屋根等、様々な技術レベルの構法の解明を 進め、位置づけや関連を明確にすることが望まれる。

調查にご協力頂いた草牧信彦様、別府市教育委員会の皆様、古林 知恵さん、和田洸君に心より謝意を表します。

注

注 1) 平成 18 年にこの地域固有の温泉噴気と碧粘土の化学反応で生じる湯の 花の結晶を生産する技術が「別府市明樊温泉の湯の花製造技術」として 国の無形文化財に指定された。また、平成 24 年には湯の花製造に代表さ れる温泉熱を生業や生活に利用した明攀地区の景観が「別府の湯けむ り・温泉地景観」として重要文化的景観に選定され、湯の花小屋の建築 技術の保存が進められてきた。

注 2）双首の足元が滑る場合に基䃈石のサスジリを打ち久いて座りがいいよ うに整形する程度である。なお、湯の花小屋では双首を乗せる基礎石を サスジリと呼ぶが、双首の足元のことも同じくサスジリと呼んでいる。 誤解を避けるため、本稿では双首の足元については「双首尻」と漢字表 記して区別する。

注 3）ホコダケはホコとも呼ばれるが、稲营の束のことを指寸ホコとの区別 のため、本稿ではホコダケの呼称で統一する。

\section{参考文献}

1）安藤邦廣, 乾尚彦, 山下浩一: 住まいの伝統技術, 建築資料研究社, 1983

2）恒松栖：湯の花小屋のひみつ，別府史談（20), pp. 53〜65, 2007

3）別府市教育委員会 : 伝統産業「湯の花」, ぶっぷの文化財 45 , 別府市教育 委員会, 2015

4）古林知恵，釜床美也子，和田洸：明樊温泉の湯の花小屋一逆莫きの茅莫き 小屋の構法 その 1, 日本建築学会学術講演梗概集, pp. 841 842, 2015

5）別府市：文化的景観別府の湯けむり景観保存計画，別府市，2012

6) 貝原益軒：豊国紀行， 1696

7）伊島重枝，江川吉貞 : 明樊山，鶴見七湯迺記，1845

8）恒松栖：別府における伝統産業湯の花, 別府大学短期大学部紀要 24, 別 府大学, pp. 1 11，2005

※本研究は、2014 年度公益財団法人ユニベール財団研究助成、2014 年度公 益財団法人 LIXIL 住生活財団研究助成、2014 年度日本海学グループ支援事業、 平成 27 年度科学研究費助成事業 若手研究（B）の助成を受け実施した。

[2016 年 9 月 30 日原稿受理 2017 年 1 月 6 日採用決定］ 